\title{
Growth of black spruce in
}

\author{
eastern Canada
}

In their recent article 'Applicability of Plonski's yield tables for black spruce in central and eastern Canada' (Forest. Chron. 47:282-285) L. Heger and G. L. Lowry reach a number of sweeping conclusion whose validity we wish to challenge, in particular with regard to the growth of spruce on the Island of Newfoundland. Our criticisms are set out in point form below.

1/ Heger and Lowry's site-index curves are based on data which is very heavily biased towards Ontario and Quebec. Only 5 out of 25 sample plot locations are in areas where maritime, as opposed to continental, climatic influences have any effect, and of these only 2 are on the island of Newfoundland where maritime influences are strongest. No adequate tests, using samples of approximately equal weight, have been made to determine whether Newfoundland and possibly other Atlantic Coast locations, have growth patterns meaningfully different from those of Ontario and central and western Quebec and their inclusion in one series of curves appears to have been done without adequate justification.

2) Since Heger and Lowry's data are mainly from continental Ontario and Quebec, it is perhaps not surprising that their curves are quite similar in shape to those of Plonski. The true differences between the two sets of curves, which would emerge in any practical application, are not, however, explained by the authors. The use of a reference, or index, age (commonly 50 years at breast height) is an essential step in the preparation of site-index curves, but this does not mean that all subsequent comparisons between pairs of curves must be based only on an examination of positive and negative differences above and below their crossover point (which of course, occurs at the selected index age). For example, if the curves for site Class 1 presented by Heger and Lowry in Fig. 3(A) are equated at 80 years rather than at about 55 years as at present, then the difference between them amounts to about $71 / 2 \mathrm{ft}$ at 80 years rather than the $3.4 \mathrm{ft}$ quoted by the authors. Effects of this nature may be very important in practice since only a small minority of stands can ever be at or close to index age at any one time. Differences in site-index curve shape between stands from different climatic-geologic zones, soil moisture regimes, and the like, tested by the authors in an earlier paper (PPRIC Woodlands Paper No. 27, 1971) are probably also of much greater significance than they have implied.

3 / Since doubts exist on the validity of Heger and Lowry's conclusions regarding site-index curves, similar doubts must be expressed about their yield comparisons which involve site-index estimates. We also wonder why 20 of the 124 sample plots which were originally measured (see Woodlands Report 27) were excluded from the yield determinations; were these considered aberrent for some reason, and how many of them were from Atlantic coastal regions?

4/ Our criticisms of Heger and Lowry's paper are based not only on the weaknesses of their approach as indicated above, but also on our independent and fairly comprehensive knowledge of growth patterns in Newfoundland softwood stands. Site-index curves for Newfoundland spruce presented by van Nostrand (Can. Dep. For. Publ. No 1063,

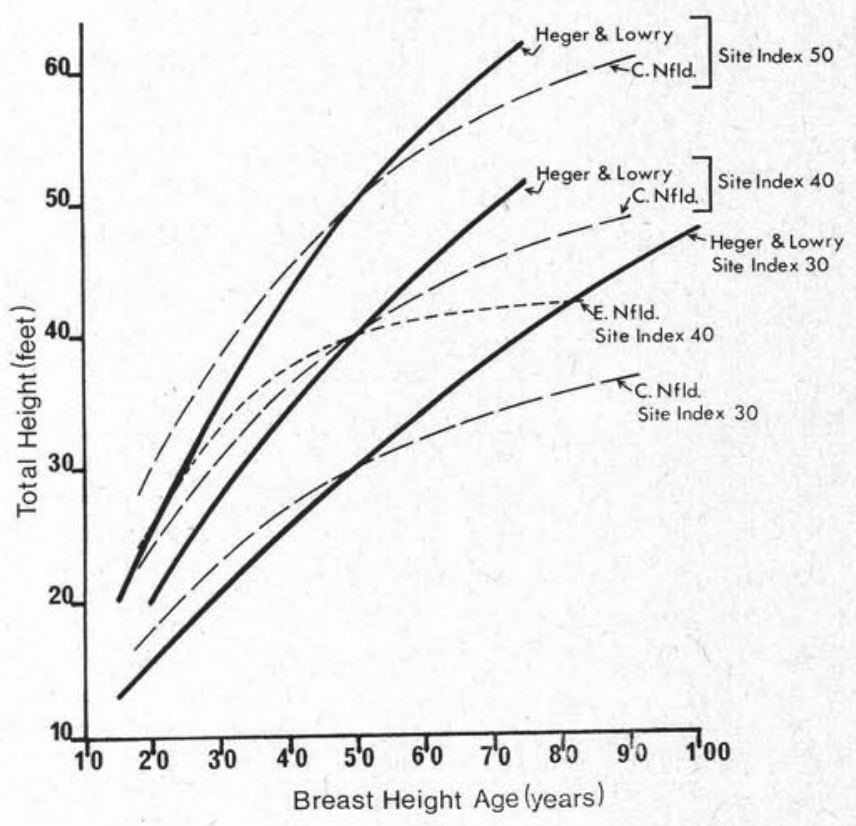

1964) and by Page (Can. Dep. Forest. Rural Dev., Inform. Rep. N-X-22, 1968) are markedly different in shape to both Plonski's and Heger and Lowry's curves (see graph). Equating our curve of $40-\mathrm{ft}$ at 50 years with Heger and Lowry's curve passing through the same point, we find differences between them of about $4 \mathrm{ft}$ at 20 years and $61 / 2$ $\mathrm{ft}$ at 80 years; if the curves are equated at 20 years they differ by about $14 \mathrm{ft}$ at 80 years. Differences are even more marked using our eastern Newfoundland curves. We should note too that the Newfoundland curves have been tested and used in a number of studies on the Island, and have been found to be reliable and accurate.

We are convinced that curve shape differences between mainland locations with a continental climate and Newfoundland (and possibly other Atlantic coastal areas) with a maritime climate are real and meaningful. Differences are quite possibly associated with differences in wind exposure (e.g. compare average annual windspeeds at St. John's, eastern Newfoundland, of $15.7 \mathrm{mph}$, and at Gander, central Newfoundland, of $14.0 \mathrm{mph}$, with those, for example, for Goose Bay, Labrador, $9.5 \mathrm{mph}$; Chibougamau, Que., 6.7 mph; Kapuskasing, Ont., $9.7 \mathrm{mph}$ ). In any case, whatever their cause, real curve shape differences are present, and lead us to reject Heger and Lowry's contention that Plonski's yield curves are applicable in the Boreal forests from Saskatchewan to Newfoundland; at least for the Island of Newfoundland, and possibly for other Atlantic coastal regions, we maintain they are not.

G. Page and R.S. van Nostrand Newfoundland Forest Research Centre Canadian Forestry Service St. John's, Newfoundland 